\title{
The Heuristics of Fear: Can the Ambivalence of Fear Teach Us Anything in the Technological
} Age?

Roberto Franzini Tibaldeo (University of Turin)

\section{Introduction. In Search of an Ethics for the Technological Age}

For several reasons our present day civilization has become increasingly complex. Indeed, complexity seems to be one of the most eloquent characteristics which unifies several aspects of today's world, such as epistemology, science, technology, politics, economy, culture, society, and so on. Complexity as the result of the modern age or as its greatest creation. However, complexity has also highlighted the intrinsic limits of modernity: as such, its scientific method and its gnoseological claim to simplicity, abstraction, and reductionism have become inadequate in comprehending and reacting to phenomena which emerged during the closing decades of the twentieth century, such as globalization, financial emergencies, ecological crisis, bioethical issues etc. What is worse, until recently modernity has simply ignored the extent of human technological action upon these events.

What is now at stake is not only modernity's legitimacy in relation to previous eras, nor the fact that it has allegedly come to a dead end and ought to be overcome ${ }^{1}$. Far beyond these theoretical questions, what is now urgent is - to quote Hans Jonas - to go in "search of an ethics for the technological age" 2 . This is indeed a delicate task, since what is required is to investigate the phenomenon of technology in the light of the present day complexity, which is to be assumed as a sign of the times and an opportunity for reflecting upon the meaning and the consequences of individual and collective action ${ }^{3}$.

\footnotetext{
${ }^{1}$ For the debate on modernity's legitimacy, see for example Löwith 1949; Heidegger 1954; Koselleck 1979; Del Noce 1964; Del Noce 1970; Blumenberg 1983; Jonas 1966; Jonas 1974; Jonas 1984a; Severino 1971; Severino 1979 (see also: Giddens 1990).

2 See the subtitle of: (Jonas 1984a).

3 Against the abstractness of Cartesianism and against its ideology of simplification, complexity is able to gain a higher degree of comprehension of reality. In terms of complexity, knowledge is not only the result of a theoretical operation, but involves the whole range of human capacities, that is praxis, emotions, imagination, creativeness, care, dialogue, critical thinking, multi-logical thinking etc. See: Morin 1991; Lipman 1995; Lipman 2003. On the notion of complexity in relation to politics,
} 
As shown in Hans Jonas' Imperative of Responsibility, twentieth century's technological development marks the peak of three centuries of generalized progress and advancement of the Western societies ${ }^{4}$. However, in the last century Jonas believes that this overall trend in mankind's achievement has reached unheard-of levels in the exploitation of nature. One of the aims appears to be an indiscriminate programme to rule over any form of life and to reduce life to an "artificial phenomenon".

Hans Jonas ${ }^{6}$ shows that today's technology - with its "Promethean power" (Jonas 1984a, x) - has achieved such results by means of a qualitative transformation. Indeed, it is able to generate worldwide effects, and only recently has humankind started to gain awareness of the cumulative and irreversible character of such effects on ecological equilibriums (see: Jonas 1984a, Ch. 1). However, problems raised by technology are not only limited to ecological issues. The possibility of achieving forms of manipulation, control

globalization and fear, see also: Beck 1992; Giddens 1990; Bodei 1991a; Bauman 1992; Bauman 1999; Beck 1999; Marramao 2003; Pulcini 2013.

${ }^{4}$ Among other philosophers who reflect on these topics from a critical perspective, I can mention O. Spengler, M. Heidegger, E. Jünger, J. Ortega y Gasset, G. Anders, B. Croce, H. Arendt, E. Severino, J. Rawls, A. Naess etc. (see: Nacci 2000).

${ }^{5}$ See for instance the beginning of Hannah Arendt's The Human Condition: 'The earth is the very quintessence of the human condition, and earthly nature, for all we know, may be unique in the universe in providing human beings with a habitat in which they can move and breathe without effort and without artifice. The human artifice of the world separates human existence from all mere animal environment, but life itself is outside this artificial world, and through life man remains related to all other living organisms. For some time now, a great many scientific endeavors have been directed toward making life so "artificial", toward cutting the last tie through which even man belongs among the children of nature. It is the same desire to escape from imprisonment to the earth that is manifest in the attempt to create life in the test tube' (Arendt 1958, 2).

${ }^{6}$ Hans Jonas (1903-1993) was a philosopher of Jewish origins. In the 1920s he attended the universities of Freiburg and Marburg, and studied with E. Husserl, M. Heidegger, and R. Bultmann. His earlier research focused on the topic of Ancient Gnosis, which Jonas interpreted in the light of Heidegger's existentialism. However, afterwards Jonas started to doubt about the validity of his teacher's philosophy. The break became even deeper in 1933, when Jonas emigrated from Germany, while Heidegger joined the Nazi party. In 1939 Jonas resolved to fight in the English army against Nazi Germany. After the war he tried to settle in Palestine, but then decided to move with his family to Canada. He started a new life, and also his research changed address. Jonas developed a philosophy of life, which was to overcome the limits of Modernity and of its dualistic and nihilistic interpretation of the phenomenon of life. After moving to New York, where in 1953 he found a post at the New School for Social Research, he developed the ethical and political consequences of his 'biological philosophy' (see Jonas, Phenomenon of Life). However, only in 1979 his ethical thinking found a more complete form in Das Prinzip Verantwortung (The Imperative of Responsibility), the first book he wrote in German after leaving Germany in the 1930s. Das Prinzip Verantwortung signs the beginning of the third period of Jonas' thinking, the aim of which is to reflect on the ethical consequences of human technology on the phenomenon of life. See: Jonas 2008. 
or power on human and non-human life clearly gives rise to fundamental political and bio-political, economic, scientific, ethical and bio-ethical issues.

In Jonas' perspective these enquiries are embedded in an overall ontological horizon, which posits being "absolutely as the better over against nonbeing" (Jonas 1984a, 81) and therefore as a value, and postulates that the capacity to have purposes is real, is 'a good-in-itself' and therefore is a value (see: Jonas 1984a, 80, also Ch. 3 and Ch. 4; also: Jonas 1966; Franzini Tibaldeo 2009). According to Jonas this "ontological axiom" (Jonas 1984a, 80) provides the foundation of human action and is therefore able to indicate the limits of technological activities.

However, apart from these ontological considerations, what is interesting is that Jonas' 'ethics for the technological age' takes the peculiar shape of an ethics of responsibility, whose main characteristics are the intrinsic relationship between freedom and responsibility and the so called 'heuristics of fear'. Indeed, according to Jonas, the fear for the survival of worldly life might be of great help in investigating the possibilities-for and limits-to technological action.

\section{Hans Jonas' Ethics of Responsibility}

According to Jonas, human beings experience freedom by gaining consciousness of the fact they have (or can have) power over reality. Hence, man experiments the unity of freedom and responsibility. In addition to this, human beings apply their power over reality with the mediation of knowledge and free will (Jonas 1984a, 129-130; also Jonas 1966).

However, the development of technology seems to lead human freedom into temptation. Technology - believes Jonas - deludes human freedom with two false promises. The first is almightiness, thanks to which all humans can easily realize whatever they desire. The second is innocence, thanks to the fact that technology actually separates freedom from responsibility, and fails to provide human liberty with the due consideration of the impact of its own deeds 7 .

The opposing issues of the ontological axiom and the recent technological threat persuade Jonas to meditate on the complex relationship between freedom and responsibility, in order not to accomplish what is inadmissible (Jonas 1984a, 280-281). This is the reason for which Jonas grants

7 Concerning being responsible, Jonas writes: "To be de facto responsible in some respect for someone at some time ... belongs as inseparably to the being of man as his a priori capacity for it - as inseparably indeed as his being a speaking creature - and is therefore to be included in his definition ... In this sense an "ought" is concretely given with the very existence of man; the mere property of being a causative subject involves of itself objective obligation in the form of external responsibility. With this, he is not yet moral, but a member of the moral order, that is, one who can be moral or immoral" (Jonas 1984a, 99). 
a privilege to actions which present themselves in the shape of "responsibility for the welfare of others" (Jonas 1984a, 92). The essence and the goal of such acts is indeed nothing else but the other's happiness as such.

This is the way by which 'power in its transitive causality becomes committed, and committed in the double sense of being objectively responsible for what is thus entrusted to it, and affectively engaged through the feeling that sides with it, namely, "feeling responsible" (Jonas 1984a, 92). Hence, responsibility means that the fulfilment of others depends to some extent on the power of my freedom. The intrinsic value of this goal is of course independent from me. But the fact that its realization may also depend on my power makes it at the same time something belonging to my concern.

Jonas believes that the ontological axiom cries out to man. The outcry addresses the hendiadys of freedom and responsibility, and demands an answer from man. The ontological axiom shows its ethical relevance by acting as a prudential moral law on human freedom, which has the responsibility of willingly ensuring self-discipline, self-control, and self-limitation of its power (see: Jonas 1984a, 129-130) ${ }^{8}$ If this does not happen, because of the reluctance to value natural and ecological limitations, the subject of freedom vanishes. As a consequence, freedom, responsibility or any kind of value are nothing but flatus vocis. For this very reason Jonas points out the following fundamental moral duty:

... the existence of mankind comes first, whether deserved on its past record and its likely continuation or not. It is the evertranscendent possibility, obligatory in itself, which must be kept open by the continued existence. To preserve this possibility is a cosmic responsibility - hence the duty for mankind to exist. Put epigrammatically: the possibility of there being responsibility in the world, which is bound to the existence of men, is of all objects of responsibility the first (Jonas 1984a, 99).

However, there is no way of being assured a priori of the fact that human behaviour, whether individual and collective, will succeed in respecting the ontological axiom. Since freedom is an essentially open, risky and unforeseeable adventure, there is no guarantee that the power of human freedom will actually succeed in protecting life and its ontological value. Quite the opposite, it seems that because of its technological strengthening, human power easily and quickly generates ambivalent effects, or produces consequences which may doom humanity.

According to Jonas, the threat is real and tangible. Because of the significance of the prize at stake, Jonas prefers to give priority to "the Bad over the Good Prognosis" (Jonas 1984a, 31). He also firmly claims that the central issues be raised, that adequate priorities for action be chosen, and - what's

${ }^{8}$ According to Paul Ricoeur the virtue of prudence suggested by Jonas is rooted in the Greek notion of phronesis (Ricoeur 1994, 44-48). 
more - that the temptation of employing ideology to escape responsibilities be set aside. As examples of such a negative use of ideology, Jonas chooses the "political eschatologies of history" or "the non-political belief in endless progress" (Jonas 1984a, 109). In both cases technology has been adopted as a device for fulfilling positive aims (in politics, economics, society etc.). At least, this is what their worshippers believed. However, according to Jonas this is a wholly misled belief. The fact is that - as brilliantly shown in The Phenomenon of Life - technology overthrows the goals of human action: the desired goal becomes a means subjected to the self-perpetuation of the technological system as such (see: Jonas 1966, 188-210) ${ }^{9}$. Moreover, this causes a dangerous alteration in ontology and the fact that its practical consequences remain almost veiled.

\section{Fear as a Guide to Responsibility}

At this point of the discussion Jonas introduces the expression of the "heuristics of fear", with which he states the amplified relevance for ethics of the "revulsion of feeling which acts ahead of knowledge, to apprehend the value whose antithesis so affects us. We know the thing at stake only when we know that it is at stake" (Jonas 1984a, 27; see also: Spinelli, Verde 2011). And he continues as follows: "We know much sooner what we do not want than what we want. Therefore, moral philosophy must consult our fears prior to our wishes to learn what we really cherish" (Jonas 1984a, 27). However, Jonas adds that the heuristics of fear ought only to recover an adequate emotional motive for acting responsibly in the face of current ethical dilemmas:

\footnotetext{
${ }^{9}$ In this chapter Jonas considers the specificity of the modern knowledge of nature. He quotes F. Bacon's idea that "knowledge must deliver man from the yoke of necessity by meeting necessity on its ground, and achieves freedom for him by delivering the things into his power" (Jonas 1966, 192). This is precisely what modern science and technology have tried to realize, thanks to their methodological reductionism and quantitative interpretation of being. As a result, 'the modern knowledge of nature, very unlike the classical one, is a "know-how" and not a "know-what," and on this basis it makes good Bacon's contention that knowledge is power' (Jonas 1966, 204). Any question concerning the "meaning" of being, or its "value", is - therefore considered unworthy. All that matters, is to gain power over reality and to dominate it with science and technology. "But - writes Jonas - if ever we entrust or resign ourselves wholly to the self-corrective mechanics of the interplay of science and technology, we shall have lost the battle for man. For science, with its application governed solely by its own logic, does not really leave the meaning of happiness open: it has prejudged the issue, in spite of its own value-freedom. The automatism of its use - insofar as this use carries beyond the recurrent meeting of the recurrent emergency created by itself - has set the goal of happiness in principle: indulgence in the use of things. Between the two poles of emergency and indulgence, of resourcefulness and hedonism, set up by the ever-expanding power over things, the direction of all effort and thereby the issue of the good tends to be predecided. But we must not let that issue be decided by default" (Jonas 1966, 208-209). As for the modern methodological reductionism (see: Wolters 2010).
} 
"although, in consequence, the heuristics of fear is surely not the last word in the search for goodness, it is at least an extremely useful first word" (Jonas 1984a, 27) ${ }^{10}$.

For humankind the fear for the survival of life on Earth becomes a way of gaining consciousness about the excessive precariousness and risks of the present era11. At the same time, fear elucidates the possible relationship between irresponsibility and the human technical project. Since technology turns human action into an irresponsible excess of action (indeed, "Dynamism is the signature of modernity") (Jonas 1984a, 119), Jonas, on the other hand, believes that an ethics of responsibility ought to preserve "the heritage of a past evolution" (Jonas 1984a, 32), whose ontological value was intensely analyzed by the "biological philosophy" highlighted in The Phenomenon of Life. Jonas insists on the essential solidarity of human life with the general phenomenon of life. The complex dynamics of life's evolution has an ontological, transcendent and metaphysical meaning, and so the humanity - as part of that overall adventure and evolution - has the "supreme duty to preserve it intact" (Jonas 1984a, 33; see: Jonas 1984a, 119-122, 127-129; Jonas 1985; Frogneux 2001, Franzini Tibaldeo 2009). As a consequence, mankind today is committed to acting so that humankind tomorrow will be able to respond to the outcry of terrestrial life, that is, it will be able to assume the ontological duty of responsibility. So this is our current obligation towards future mankind:

This means, in turn, that it is less the right of future men (namely, their right to happiness, which, given the uncertain concept of 'happiness', would be a precarious criterion anyway) than their duty over which we have to watch, namely, their duty to be truly human: thus over their capacity for this duty - the capacity to even attribute it to themselves at all - which we could possibly rob them of with the alchemy of our 'utopian' technology JJonas 1984a, 42).

\footnotetext{
${ }^{10}$ See also the following extract from The Phenomenon of Life, in which Jonas suggests how to face problems generated by an uncritical use of technology: "Thus even with the pressure of emergencies upon us we need a view beyond them to meet them on more than their own terms. Their very diagnosis (wherever it is not a case of extremity) implies at least an idea of what would not be an emergency, as that of sickness implies the idea of health; and the anticipation of success inherent in all struggle against danger, misery, and injustice must face the question of what life befits man" (Jonas 1966, 209). See also: Jonas 1985, Ch. 3. It is important to notice that, according to Jonas, the imperative of responsibility is absolutely not grounded in the heuristics of fear (as erroneously stated, for instance, by Denis Müller - see: Müller 1993, 223-35), but in an overall ontological theory of responsibility.

11 The relevance of Jonas' "heuristic of fear" to understanding vulnerability transformations related to technology has been recently underlined by Mark Coeckelbergh $(2013,102)$.
} 
At first sight, it seems that the prophecy of doom which accompanies Jonas' heuristics of fear casts a pessimistic light on his reflections. However, this is not the case. Instead, Jonas never stops repeating that negative prophecy is always made "to avert its coming" (Jonas 1984a, 120). Because of his criticism of contemporary technology, Jonas cannot be considered a prophet of doom, a reactionary or an opponent of progress ${ }^{12}$. On the contrary, I believe that the meaning of Jonas' claim for responsibility essentially consists of his will to highlight the basic ambiguity of human freedom. Due to this characteristic, freedom is open to good, but also to bad; it may welcome and respect the bond of ontological value, but it may also choose to violate or ignore that very same value.

The ambivalence of freedom is man's most specific feature. According to Jonas, man is truly ambiguous, and so today's homo technologicus cannot but be ambiguous. In this respect, Jonas warns that humankind waits for no utopian improvement, unlike those ideologies and utopias that claim to fight for anthropological enhancement (see: Jonas 1984a, 200-201, 383-384) ${ }^{13}$. The ethics of responsibility offers a different kind of hope. Indeed, "hope is a condition for action" (Jonas 1984b, 391) and a heuristics of fear ought to be used "in counterbalance to a heuristics of hope" (Jonas 1984a, 203). However, the ethics of responsibility gives fear "its rightful place": "There are times continues Jonas - when the drive needs moral encouragement, when hope and daring rather than fear and caution should lead. Ours is not one of them" (Jonas 1984a, 203). On the other hand, fear ought not grow to the extent that action becomes paralyzed. A correct interpretation of fear - states Jonas ought to inspire the 'courage of responsibility', which takes care of an object whose existence depends on man's ability to act with wisdom, resoluteness,

12 On the contrary, Jonas declares that ethics ought to preserve those values and to prevent falling into a lifeboat situation (see: Jonas 1985). However, this aspect does not seem to be perceived by scholars who believe that Jonas' ethics is antidemocratic and in favour of eco-tyranny. See, among others: Landkammer 1990, 423-9; Wolin 2001, 123; Frogneux 2007; Seidel \& Endruweit 2007.

${ }^{13}$ In the last chapter of The Imperative of Responsibility Jonas offers harsh criticism of Ernst Bloch's Das Prinzip Hoffnung (1959) and of his ontology of 'not-yet'. Indeed, according to Jonas, the main risk is that such ontology may ally itself with the technological and Baconian ideal (see: Jonas 1984a, 142-3, 192-200). However, afterwards Jonas admitted that his criticism had been too harsh. The point was that Jonas was frightened that the Blochian philosophy could be subdued to political movements (see: Jonas 1991, 132-3; Becchi 2000, 17-18). On the relationship between Jonas and Bloch, see: Bodei 1991b, 5-13; Bodei 1991c, 231-234. As for currently debated topics like human enhancement and transhumanism, Jonas' reflections are highly critical of their melioristic fervour and neglect of the risks related to the irreversibility of technological interventions, leading to consequences which cannot be controlled (see: Jonas 1974b, 143-5; Habermas 2003, 62-3). Vice versa, the transhumanist philosopher Nick Bostrom criticises both Jonas and Habermas as conservative thinkers (Bostrom 2005a, 33-46; Bostrom 2005b, 1-25). See as well: Gammel 2013, 239-267. 
promptness, moderation, and circumspection (see: Jonas 1984a, 204; Jonas 1984b, 391; also: Pulcini 2013) ${ }^{14}$. The vulnerable phenomenon of terrestrial life - into which human life is rooted - is such an object, and its perpetuation needs man's attentive and active care. According to Jonas, this aim means more than the mere indication of actions not to be done. More than just this, human freedom ought to reflect positively on itself, on its own being-in-theworld, and on the object of its responsibility - that is, life.

The fragile and vulnerable object of responsibility calls for care. What precisely should human responsibility care for? Jonas answers that we are responsible for "the idea of Man, which is such that it demands the presence of its embodiment in the world" (Jonas 1984a, 43). The idea of man specifies the primary imperative for ethics and insists "equally on the that and the what of obligatory existence" (Jonas 1984a, 43; also: Jonas 1966, 106). According to Jonas, human beings personify one of the main ontological characteristics of life, namely its dynamic and self-transcending development (see Jonas' biological philosophy in: Jonas 1966). Human life is essentially open to the future and to self-transcendence. This is the reason for which an "ought" filters through the "being" of human life: future actions ought to respect the fact that human freedom and life always express more than what, strictly speaking, is there. Individual and collective freedom ought never to put at stake the promise of future which expresses life's ontological feature.

For this reason, Jonas ends his masterpiece with an appeal to preserve the integrity of man's essence, since "something sacred" discloses itself through humankind, something "inviolable under no circumstances (and which can be perceived independently from religion)" (Jonas 1979, 393). Against the triumphalism of utopian ideologies, Jonas reaffirms that humanity courageously accepts its demanding task of fulfilling freedom and responsibility:

The time for the headlong race of progress is over, not of course for guarded progress itself. Humbled we may feel, but not humiliated. Man's mandate remains exacting enough outside of paradise. To preserve the integrity of his essence, which implies that of his natural environment; to save this trust unstunted through the perils of the times, mostly the perils of his own overmighty deeds - this is not a utopian goal, but not so very modest a task of responsibility for the future of man on earth. (Jonas 1984a, 201-202).

\footnotetext{
${ }^{14}$ Although Jonas and Lars Svendsen (who recently published A Philosophy of Fear) share the aim of restoring the full meaning of human freedom and responsibility, they disagree about the role played by fear: while according to Jonas fear ought to play a constructive role, Svendsen is more critical and polemical. He believes that the proper question to be posed is: what role fear ought to be allowed to play in our lives? (see: Svendsen 2008).
} 


\section{Conclusions}

The importance of Jonas' reflections lies in the fact that he points out the essential ambivalence of human freedom, and on the fact that he puts this feature in relation to modern technology. The risks connected to and generated by the massive employment of technology made Jonas sensitive to the idea of the preservation of life and of its value for human freedom. However, since technology is a product of human freedom, he also became aware of the fact that humanity ought to use its prerogatives cautiously. In this respect, fear may play an important role.

In particular, as far as the ecological crisis is concerned, fear compels us to think no longer about human progress in terms of 'increase', but instead in terms of 'responsibility', 'sobriety', and 'decrease' (for other reflections beyond Jonas on these themes, see: Passmore 1974; Hösle 1991; Latouche 1995; Beck 1999; Marramao 2003). Jonas' Imperative of Responsibility adds something that is most important: any decision about new parameters to be adopted for individual and collective action ought never to forget respect for the essence of man - that is, freedom - and ought never to forget that freedom is indeed ambivalent. So, properly speaking, there is no guarantee that responsibility will effectively succeed in fighting against irresponsibility. Fear - argues Jonas - may therefore be very useful, since it may lead to responsibility and supply a first motive for responsible action. Moreover, negative prophecies and fear may offer powerful devices for ethical theories and practice. The strength of fear consists of its capacity to unify all the dimensions of the human being (individual and collective, rational and emotional, theoretical and practical etc.). Moreover, fear greatly intensifies imagination.

Jonas talked also about the possibility of suspending democracy in order to face the problem of the survival of mankind. However, these words are provocative. He hints at eco-tyranny only to say that that is what absolutely and in any case ought to be avoided (see: Jonas 1984a, 150-151, 173-174; Jonas 1987). As shown above, respect for human freedom always comes first. And, secondly, fear is never to be used for ideological purposes, or for purposes which are harmful to freedom and its ambivalence.

In the light of the previous speculation, however, there is a possible difficulty concerning the effectiveness of responsibly used fear in resolving problems such as the ecological crisis. On the one hand, it is necessary for freedom to limit itself by containing the impact of its technological effects on nature, economy, society, and so on. In this respect, there certainly are slight signals that it is the democracies that are proceeding in this direction, despite hesitation, sluggishness, resistance, and contradictions. However, on the other hand, human freedom and the democratic handling of ecological politics do not appear to have sufficiently fulfilled their goals (see: Hösle 1991). The risk is that for very many reasons - including a form of overall cultural 
backwardness in the face of the complexity of our era - human freedom and democracy fail their duty to propose farsighted actions to face adequately and effectively those global problems. Further problems could arise if this doubt were to spread among people and become frustration, or if it were to cause people to shut themselves in their own fear or interests, or finally if it were to set the premises for a generalized indifference toward public matters. In these cases the positive use of fear would probably be exploited and individual freedom would most likely opt for its irresponsible cupio dissolvi in face of the negative and terroristic use of fear by tyrannies or elitist democracies. ${ }^{15}$

A possible answer to these contradictions ought to assume the complexity of our times, and ought to handle it through new processes and awareness. The ethical reflection based upon the idea of responsibility and assuming fear as a guide to responsible action may be very helpful. However, the philosophical analysis of the hendiadys of freedom and responsibility ought to be discussed not only from an individual point of view, but also in its public relevance. ${ }^{16}$ Fear produces positive results if it is discussed in public and if its discussion concerns not only theoretical and formal matters, but is able to involve the whole of the person (practical, emotional, imaginative etc.). As a result, individuals may become aware of the fact that fear is a question of public relevance, a question with which everyone's happiness and realization is deeply intertwined.

\section{References}

Apel, K.-O. 1988. Diskurs und Verantwortung. Frankfurt am Main: Suhrkamp. Arendt, H. 1958. The Human Condition. Chicago: University of Chicago Press. Bauman, Z. 1992. Modernity and Ambivalence. Cambridge: Polity Press. Bauman, Z. 1999. In Search of Politics. Cambridge: Polity Press. Becchi, P. (ed.). “Hans Jonas. Due lettere”. Ragion Pratica 8 (2000): 17-31. Beck, U. 1992. Risk Society. Towards a New Modernity. London-Newbury Park: Sage.

\footnotetext{
15 This is indeed the core thesis of (Svendsen 2008). As regards this topic, the author seems to have been inspired by the reflections of Hans Jonas.

16 This philosophical meditation ought to overcome the formal and abstract paradigm for public ethics set by J. Habermas' and K.-O. Apel's Diskursethik (Apel 1988; Habermas 1990). A deeper reflection upon the complex and social meaning of man, rationality and knowledge is required. In this direction, it is possible to consider not only Jonas' ethical meditation, but also other thinkers, such as E. Morin, G. Bateson, U. Bronfenbrenner, and M. Lipman. In the last decades these scholars have developed lines of thought, such as the theory of complexity, the ecology of mind, the ecology of human development, the socio-constructivism, and the philosophy for children and community. In spite of their different fields of research, these scholars seem to share ideas such as the complexity of human rationality, the unity of theory and praxis, and of reason and emotions, the relevance of technological development, the ethical relevance of human knowledge etc. See for instance: Tibaldeo 2013.
} 
Beck, U. 1999. World Risk Society. Cambridge: Polity Press.

Blumenberg, H. 1983. The Legitimacy of the Modern Age. Cambridge, MA: MIT Press, 1983.

Bodei, R. 1991a. Geometria delle passioni. Paura. speranza. felicità: filosofia e uso politico. Feltrinelli: Milano.

. 1991b. "La speranza dopo il tramonto delle speranze." Il Mulino 333: 5-13.

—_-. 1991c. "Principio speranza/Principio responsabilità." Iride 6: 231-4.

Bostrom, N. 2005a. "In difesa della dignità postumana." Bioetica 13 (4): 33-46.

-_- 2005b. "A History of Tranhumanist Thought." Journal of Evolution and Technology 14 (1): 1-25.

Bronfenbrenner, U. 1979. The Ecology of Human Development. Experiments by Nature and Design. Cambridge: Harvard University Press.

Coeckelbergh, M. 2013. Human Being \& Risk. Enhancement, Technology, and the Evaluation of Vulnerability Transformations. Dordrecht: Springer.

Del Noce, A. 1964. Il problema dell'ateismo. Bologna: Il Mulino.

-_- 1970. L'epoca della secolarizzazione. Milano: Giuffrè.

Franzini Tibaldeo, R. 2009. La rivoluzione ontologica di Hans Jonas. Uno studio sulla genesi e il significato di 'Organismo e libertà'. Milano: Mimesis.

———. 2013. “Un'esistenza indivisibile. Complessità, governance e responsabilità in età globale." Governare la paura. http://governarelapaura.unibo.it/

Frogneux, N. 2001. Hans Jonas ou la vie dans le monde. Bruxelles: De Boeck \& Larcier.

- - - 2007. "Pluralität à la Robinson Crusoe. Ist die Anthropologie von Hans Jonas eingeschränkt durch den Archetyp des Einzellers?." In: R. Seidel \& M. Endruweit (eds.) Prinzip Zukunft: im Dialog mit Hans Jonas. Paderborn: Mentis, 167-183.

Gammel, S. 2013. "Achtung und Verachtung der Natur. Hans Jonas' Denken zwischen Transhumanismus und Biokonservativismus." In: G. Härtung-Kristian Köchy, J. C. Schmidt, \& G. Hofmeister (eds.), Naturphilosophie als Grundlage der Naturethik. Zur Aktualität von Hans Jonas. Freiburg-München: Alber, 239-267.

Giddens, A. 1990. The Consequences of Modernity. Cambridge: Polity Press.

Habermas, J. 1990. Moral Consciousness and Communicative Action. Cambridge: Polity.

- - . 2003. The Future of Human Nature. Cambridge: Polity Press.

Heidegger, M. 1977. "Lectures and Essays." In: idem, The Question Concerning Technology and Other Essays. Ed. by W. Lovitt. New York: Harper \& Row: 3-35.

Hösle, V. 1991. Philosophie der ökologischen Krise. München: Beck.

Jonas, H. 1964. "Heidegger and Theology." The Review of Metaphysics 18: 20733. 
-——. 1966. The Phenomenon of Life. Towards a Philosophical Biology. New York: Harper \& Row, 1966.

-_-. 1974a. Philosophical Essays. From Ancient Creed to Technological Man. Englewood Cliffs: Prentice-Hall.

-_—. 1974b. "Biological Engineering - A Preview". In: idem, Philosophical Essays. Englewood Cliffs (NJ): Prentice-Hall: 141-67.

- - 1984a. The Imperative of Responsibility. In Search of an Ethics for the Technological Age. Chicago: University of Chicago Press.

-_-1 1984b. Das Prinzip Verantwortung. Versuch einer Ethik für die technologische Zivilisation. Frankfurt am Main: Suhrkamp.

-——. 1985. Technik, Medizin und Ethik. Praxis des Prinzips Verantwortung. Frankfurt am Main: Insel.

———. 1987. Wissenschaft als persönliches Erlebnis. Göttingen: Vandenhoeck \& Ruprecht.

-——. 1988. "Heideggers Entschlossenheit und Entschluss". In: G. Neske \& E. Kettering (eds.), Antwort. Martin Heidegger im Gespräch. Stuttgart: Neske: 221-229.

-_- 1991. Erkenntnis und Verantwortung. Gespräch mit Ingo Hermann in der Reihe 'Zeugen des Jahrhunderts'. Ed. by I. Hermann. Göttingen: Lamuv.

———. 1992. "Fatalismus wäre Todsünde". Freie Universität-Info (Berlin Freie Universität) 7: 2-3.

-——. 2008. Memoirs. Lebanon (NH): Brandeis University Press, 2008.

Koselleck, R. 1979. Vergangene Zukunft: zur Semantik geschichtlicher Zeiten. Frankfurt am Main: Suhrkamp.

Landkammer, J. 1990. "Le domande estreme e le risposte evanescenti di H. Jonas". Filosofia politica 4: 423-429.

Latouche, S. La Megamachine. Raison techno-scientifique. Raison économique et le mythe du Progrès. Essais à la mémoire de Jacques Ellul. Paris: La Découverte.

Lipman, M. 1995. "Moral Education Higher-order Thinking and Philosophy for Children." Early Child Development and Care 107: 61-70.

-_- 2003. Thinking in Education. Cambridge, MA: Cambridge University Press.

Löwith, K. 1949. Meaning in History. The Theological Implications of the Philosophy of History. Chicago: The University of Chicago Press.

Marramao, G. 2003. Passaggio a Occidente. Filosofia e globalizzazione. Torino: Bollati Boringhieri.

Morin, E. 1991. Introduction à la pensée complexe. Paris: ESF.

Müller, D. 1993. "L'horizon temporel de l'éthique et le poids de la responsabilité". In: G. Hottois (ed.), Aux fondements d'une éthique contemporaine: H. Jonas et H. T. Engelhardt en perspective. Paris: Vrin: 223-235. 
Nacci, M. 2000. Pensare la tecnica. Un secolo di incomprensioni. Roma-Bari: Laterza.

Passmore, J. 1974. Man's Responsibility for Nature. Ecological Problems and Western Traditions. London: Duckworth.

Pulcini, E. 2013. Care of the World. Fear, Responsibility and Justice in the Global Age. Dordrecht: Springer.

Ricoeur, P. 1994. "Le concept de responsabilité. Essai d'analyse sémantique". Esprit 206: 28-48.

Seidel, R., Endruweit, M. (eds). Prinzip Zukunft: im Dialog mit Hans Jonas. Paderborn: Mentis.

Severino, E. 1971. Essenza del nichilismo. Milano: Adelphi.

- - - 1979. Techne. Le radici della violenza. Milano: Rusconi.

Spinelli, E. Verde, F. 2011. "Hans Jonas: The Function of Fear in Lucretius and Hobbes". Paradigmi 2: 183-195.

Svendsen, L. 2008. A Philosophy of Fear. London: Reaktion Books.

Wolin, R. 2001. Heidegger's Children. Hannah Arendt. Karl Löwith. Hans Jonas. and Herbert Marcuse. Princeton-Oxford: Princeton University Press.

Wolters, G. 2010. Ambivalenz und Konflikt. Katholische Kirche und Evolutionstheorie. Konstanz: Universitätsverlag Konstanz. 


\title{
Roberto Franzini Tibaldeo (Turin)
}

\section{The Heuristics of Fear: Can the Ambivalence of Fear Teach Us Anything in the Technological Age?}

\begin{abstract}
The paper assumes that fear presents a certain degree of ambivalence. To say it with Hans Jonas (1903-1993), fear is not only a negative emotion, but may teach us something very important: we recognize what is relevant when we perceive that it is at stake. Under this respect, fear may be assumed as a guide to responsibility, a virtue that is becoming increasingly important, because of the role played by human technology in the current ecological crisis. Secondly, fear and responsibility concern both dimensions of human action: private-individual and public-collective. What the 'heuristics of fear' teaches us, is to become aware of a deeper ambivalence, namely the one which characterizes as such human freedom, which may aim to good or bad, to self-preservation or self-destruction. Any public discussion concerning political or economic issues related with human action (at an individual or collective level) ought not to leave this essential idea out of consideration.
\end{abstract}

Keywords: Fear, Responsibility, Hans Jonas, Heuristics of Fear, Technological Risks.

Ethics in Progress (ISSN 2084-9257). Vol. 6 (2015). No. 1. pp. 225-238.

doi: 10.14746/eip.2015.1.9 